\title{
PREFACE
}

Throughout the sub-continent of southern Africa and beyond, a major transformation is in progress, with the transfer to Africans of freehold farms formerly owned by Europeans. Formerly, European ranchers often operated across the international boundaries of Botswana, Zimbabwe and South Africa. In Botswana and Zimbabwe, Africans as new owners, are in no position to do that, but they still participate in regional relations, affected by conditions of supply and demand in the wider market. New forms of ranching have consequently evolved alongside those still practised by European settlers. Today, as in the past, the various forms of ranching continue to be closely inter-connected with, and at times even parasitic upon, indigenous stock keeping.

Despite its importance for development planning in the southern African region, virtually no in-depth research on freehold ranching had been carried out before this study. This book uses an actor-oriented analytical approach to explore the enterprises of ranching in eastern Botswana. The area includes the Tuli Block and the adjacent communal areas, to which the Tuli Block has always been connected by cattle trade and merchant enterprise. The research focuses on the settler farmers, the majority of whom settled before independence, and on the more recently settled African farmers who are mostly part-time and absentee members of the elite.

This book has two main themes. The first is an historical reconstruction of the major transformations and variations in settler ranching highlighting the differential strategies of settlers in coping with change in colonial and post-colonial government policy, as well as change in economic opportunity due to fluctuations in the market. The second theme concerns local farmers and the transformations which have been, and still are, occurring, as former tribesmen become large-scale capitalists, holding land as a commodity, along with livestock as commercial assets. The transformations epitomise many of the major social changes within a wider field in the nation as a whole.

I acknowledge with deep gratitude, the immense assistance which I received 
from Dr R. P. Werbner, my Ph.D. supervisor in the University of Manchester from January 1984 to December 1987. Through his tireless and far-reaching efforts, it has become possible for me to produce this book. Dr Werbner, with the assistance of his wife, Dr Pninah Werbner, directed with great patience and dedication my earlier work upon which this one is based. I have continued to receive his assistance and support even after completing my Ph.D. It is to him that this book owes its existence. And I remain truly grateful to his whole family for their generosity and kindness towards me both during my study period and after. Nothing I have experienced before matches their concern for me.

A number of prominent scholars have also contributed to my understanding of the issues I confront in this study, among them Dr P. T. W. Baxter, also of the University of Manchester. I am particularly grateful to Dr Ornulf Gulbrandsen of the University of Bergen, for the insight into problems of family labour in the cattle production industry within Botswana's communal areas.

In Botswana, I am indebted to Professor A. K. Datta, the Director of the National Institute for Development Research and Documentation within the University of Botswana, for his constructive criticism of my earlier drafts, and for his general encouragement. I am equally grateful to the University of Botswana for granting me the permission and financial support to carry out further field work in the Tuli Block, and the six month sabbatical during which I have put this study together. My informants, who included highly placed members of the government, notables within the Botswana society and ordinary farmers, gave freely of their knowledge and were kind to me. I thank them all and look to them for further cooperation in the future.

The final edition of this book has been produced under the supervision of Professor Norman Long in the pleasant academic atmosphere of the Department of Rural Sociology of The Tropics, Agricultural University of Wageningen in the Netherlands. I thank Professor Long and the University of Wageningen for that opportunity and privilege.

Finally, I express thanks to the four bodies that have provided financial support for this study. The University of Botswana funded my field work and also paid for my passage to the Netherlands. Living expenses during my sabbatical were covered by a generous grant from the Wenner Gren Anthropological Foundation in the United States. I also received a short fellowship from the Africa Studies Centre, University of Leiden, through the assistance of my friend Professor Wim van Binsbergen. I am grateful to Professor van Binsbergen and to all of these institutions for the financial support they have made available to me. 


\section{NOTES ON TEXT}

Throughout this study, real names are used for places, but, to protect the anonymity of individuals, pseudonyms are used for all people.

Botswana currency is reckoned in pula, abbreviated to 'P'. During my field work and up to the time of producing this book, the exchange rate was three pula to one pound sterling, and one pula to one Dutch guilder. 
